\author{
Олена Семак, \\ кандидат психологічних наук, доцент \\ кафедри загальної та клінічної психології \\ ДВНЗ «Прикарпатський національний університет \\ імені Василя Стефаника» \\ (м. Івано-Франківськ, Україна) \\ Olena Semak, \\ PhD in Education, Associate Professor, \\ Department of General and Clinical Psychology, \\ Vasyl Stefanyk Precarpathian National University \\ (Ivano-Frankivsk, Ukraine) \\ olena.semak@pu.if.ua
}

УДК 159.972:616.4

\title{
ПСИХОСОМАТИЧНІ РОЗЛАДИ ЕНДОКРИННОЇ СИСТЕМИ У ДІТЕЙ ГІРСЬКОÏ МІСЦЕВОСТІ
}

\begin{abstract}
Анотація. Стаття має за мету визначити поширеність психосоматичних розладів ендокринної системи у дітей, що проживають в гірській місцевості та проаналізувати їх зв'язок з культурними традиціями і умовами життя. У горян спостерігаються специфічні психофізіологічні стани і недуги. Їх причиною виступає унікальне сполучення кліматичних

і соціальних умов, яке напружує адаптаційні механізми, зумовлює порушення функціонування органів і систем. Тому вивчення проблем охорони здоров'я дітей гірської місцевості важливе як в загальнонауковому, так і в практичному аспекті. Особливий інтерес викликають захворювання ендокринної системи, що у тісному зв'язку з нервовою системою забезпечує нейрогуморальну регуляцію всіх життєвих функцій і підтримку гомеостазу організму. Автор виходить з визнання вагомої ролі психологічного фактору у виникненні тілесних захворювань. В роботі здійснено теоретичний аналіз проблеми: узагальнені дані щодо основних відомих причин виникнення психосоматичних розладів у дітей, наведені існуючі клінічні дані про розповсюдженість ендокринних хвороб в гірських районах, надане їх тлумачення з точки зору психогенних причин. Виділені специфічні механізми захворювань, спричинені впливом складних умов життя та формування особистості в Українських Карпатах. Обґрунтований висновок про необхідність відповідної психопрофілактичної роботи та її можливі напрями.

Ключові слова: психосоматика, розвиток психіки дитини, розлади ендокринної системи, вплив середовища існування, психологія горян.
\end{abstract}

\section{PSYCHOSOMATIC DISORDERS OF THE ENDOCRINE SYSTEM IN CHILDREN OF THE MOUNTAINOUS AREAS}

\begin{abstract}
The paper aims at determining the prevalence of psychosomatic disorders of the endocrine system in children living in mountainous areas, as well as at analyzing their connection with cultural traditions and living conditions. The author declares an important role of the psychological factor in the occurrence of bodily diseases. The theoretical analysis of the problem was carried out in the work: the main psychological mechanisms of the formation of diseases are described; the data on known causes of psychosomatic disorders of children are generalized; the meaning of emotional influences at an early age is explained. Existing results of clinical studies on the prevalence of endocrine diseases in mountainous areas (insular diabetes, hypothyroidism, hyperthyroidism, impaired puberty and metabolic disorders) are provided, and their interpretation is given in terms of psychogenic causes. The complex environmental and social conditions of life in the Ukrainian Carpathians, which lead to the formation of peculiar individual traits and behavioral patterns of mountaineers, are analyzed in detail. On this basis, specific mechanisms of occurrence of psychogenic diseases of children living in mountainous areas are named: limited social contacts, low level of general competence, lack of maternal attention and lack of educational influence of parents, dependence on the environment, excessive early demands on the independence of children, their engagement in adult activity, apathy, loss of purpose-in-life orientations, etc. The conclusion about possible directions of the corresponding psychoprophylaxis is substantiated.
\end{abstract}

Keywords: psychosomatics, development of child's psyche, disorders of endocrine system, influence of habitat, psychology of mountaineers.

\section{ВСТУП}

Постановка проблеми. Хоча гірські райони більшості країн є рекреаційно-оздоровчою зоною, у людей, що постійно проживають в цій місцині, спостерігаються специфічні психофізіологічні стани і недуги. Їх причиною виступає унікальне сполучення кліматичних і соціальних умов, яке напружує адаптаційні механізми, зумовлює порушення функціонування органів і систем. Тому вивчення проблем охорони здоров'я дітей гірської місцевості важливе як в загальнонауковому, так і в практичному аспекті. Особливий інтерес викликають захворювання ендокринної системи, що у тісному зв'язку з нервовою системою забезпечує нейрогуморальну регуляцію всіх життєвих функцій і підтримку гомеостазу організму. 
Аналіз останніх досліджень і публікацій. Психосоматичні захворювання - це розлади, у фрормуванні яких провідну роль відіграють психологічні механізми і поведінкові реакції. Вони висвічують наявність глибинних психоемоційних проблем особистості, що впливають на фізіологічні функції. Більшість пояснень цього явища надане в працях психоаналітиків (3. Фрейд, А. Адлер, А. Фрейд, М. Кляйн, Дж. Боулбі та інші). Психодинамічне трактування залучає механізм витіснення із свідомості неприйнятних думок та конверсії, завдяки чому підсвідоме «проривається назовні» у трансформованому вигляді - за допомогою розладів функцій і зміни структури органів тіла. Отже, хворобливі прояви є символічними відповідями на неприйнятну життєву ситуацію. Важливими аспектами проблеми є вибір органу, що відображає внутрішній конфлікт.

Ф. Александер в 1950 р. запропонував більш матеріалістичну теорію, згідно з якою вегетативні симптоми $є$ фізіологічним супроводом емоційних станів. Адже емоції, як позитивні, так і негативні, розмовляють мовою тіла, і навіть якщо людина їх приховує, її міміка, голос, погляд, постава, хода, блідість чи почервоніння шкіри красномовно розкажуть про переживання. В організмі немає тканини, органу і системи, яка залишалася б «незачепленою» емоціями [1]. Більшість сучасних дослідників визнають, що саме емоційна реакція (і відповідні нейро-вегетативні та ендокринні зміни) $є$ сполучною ланкою між психічною та тілесною сферами. І. Г. Малкіна-Пих відзначає, що в процесі еволюції людини поступово порушувався універсальний механізм адаптації до навколишнього середовища. Сьогодні пристосування залежить від психічних можливостей людини набагато більше, ніж від сили ії̈ м'язів, міцності кісток і швидкості бігу. Емоції, покликані мобілізувати організм, найчастіше придушуються, вбудовуються

в соціальний контекст, а з часом стають причиною руйнівних процесів в організмі [7]. Роботи в області стресу та специфічної індивідуальної відповіді на нього (Г. Сельє, Х. Вольф, Р. Лазарус та інші) суттєво збагатили розуміння психосоматичної патології. Широкого поширення набула концепція «профрілю особистості», що відшукує кореляції хвороб з конкретними конституційними властивостями і рисами характеру. Серед вітчизняних вчених зв'язок психіки з тілесними проявами вивчали І. М. Сєченов, І. П. Павлов, О. Р. Лурія, О.Ш.Тхостов та багато інших.

Питання про психологічне джерело хвороби гостро постає тоді, коли за допомогою медичного обстеження неможливо виявити фрізичну причину, що призводить до порушення функціонування організму. Психосоматичний підхід пропонує пояснення таких випадків, виходячи з уявлення про цілісність організму, нерозривну єдність психічного світу людини та ії фрізичного стану. Сьогодні він вважається одним із найбільш продуктивних способів пояснення і відповідного лікування тілесних захворювань, способом «повернути обличчям» до хворого занадто технологізовану медицину.

За даними ВОО3, від 38 до 42 \% хворих, які знаходяться на обліку у лікарів, мають порушення здоров'я психосоматичної природи [7, с. 15]. Сучасна наука має переконливі докази психогенезу багатьох ендокринних хвороб: захворювань щитовидної залози, цукрового діабету та порушень обміну, розладів харчової поведінки, дисфункції яєчників. Але якщо стосовно дорослих механізми їх виникнення достатньо чітко визначені, то дані щодо дітей досить обривчасті, несистемні та суперечливі.

МЕТА І ЗАВДАННЯ ДОСЛІДЖЕННЯ. Виходячи з визнання вагомої ролі психологічного фактору у виникненні багатьох тілесних захворювань, ми ставимо за мету визначити особливості розладів ендокринної системи у дітей, що проживають в гірській місцевості, та проаналізувати їх зв'язок з культурними традиціями і умовами життя.

\section{РЕЗУЛЬТАТИ ДОСЛІДЖЕННЯ}

В останні десятиріччя поширення ендокринних захворювань серед дітей суттєво зростає. Порушення функцій залоз внутрішньої секреції, розлади харчування й обміну речовин займають провідні місця в походженні дитячої інвалідності. Крім того, відмічається чітка тенденція зростання з віком кількості ендокринних розладів, що мають психосоматичну природу [2]. Причини цього пов'язані, найперше, із зростанням агресивності зовнішнього середовища і стресових навантажень. Д. М. Ісаєв відзначає, що в походженні значної частини ендокринної патології у дітей беруть участь захист організму або реакція особистості на психотравмуючі обставини (які діють на найбільш слабке місце). В той же час при плануванні лікування це повною мірою не враховується [4, с. 145].

Для дітей характерні як короткочасні і минущі соматизовані психічні реакції, так і психогенно спровоковані маніфестації соматичних захворювань, що призводять до органічних патологічних змін у тканинах і органах. Нервово-психічні реакції на поточні події (переляк, примус щось робити, бажання привернути увагу батьків) викликають симптоми, що імітують різні захворювання. Скарги при цьому різноманітні: найчастіше зустрічаються дисфункції шлунково-кишкового тракту (блювота і нудота, проноси і запори. метеоризм), енурез, болі різного характеру, респіраторні напади, розлади терморегуляції і регуляції сну [2, с. 4]. Розуміючи психологічну причину нездужання, батьки часто ігнорують такі симптоми. Але висновок, що у дитини психосоматичний розлад, можна зробити лише після ретельного обстеження у лікаря. Важливо розуміти, що психосоматика - не спосіб симуляції, а захворювання, що вимагає лікування. Констатація наявності психосоматичних порушень не призводить до заперечення основного діагнозу, а лише вказує на зв'язок «схильність - особистість - ситуація» [7].

У літературі поширена теза про те, що у дітей психосоматичні розлади зустрічаються набагато частіше, ніж у дорослих (від 25 до 50 \% звертань до лікарів). При цьому дитячі психогенії мають більш виражений соматичний характер, до того ж відмічені додаткові ризики виникнення захворювань [14]. Це має логічне пояснення в контексті концепції алекситимії (обмеженої здатності індивіда до сприйняття власних почуттів, їх адекватної вербалізації і експресивної передачі). Нездатність регулювати негативні емоції на психічному рівні призводить до посилення фізіологічних реакцій з боку внутрішніх органів, особливо в стресових ситуаціях. Якщо розглядати дитячий вік, то наявність алекситимії може бути цілком природна, пов'язана з варіантами недостатнього дозрівання компонентів психічного реагування. Емоції - це первинна форма психічного відображення, що формується в онтогенезі набагато раніше за мову. Людина «говорить мовою органів», так як в цей момент не має інших способів переробки своїх переживань. Очевидно, що чим молодша дитина, тим більш притаманна для неї інстинктивна, сомато-вегетативна форма реагування. У підлітковому віці через гормональну перебудову та брак життєвого досвіду часто виникають 
труднощі в ідентифікації «себе» і власних відчуттів, емоційна нестабільність, ригідність мотивацій. Ці особливості психіки можуть також виступати предиспозицією для виникнення алекситимічних проявів.

У формуванні емоцій велику роль грає наслідування. Дитина тонко сприймає емоції оточуючих, швидко починає копіювати реакції дорослих (особливо матері) та старших дітей. Крім того, в постнатальний період розвитку існує біологічно доцільна здатність до одноразового навчання з утворенням особливо міцного зв'язку (імпринтинг), що забезпечує стійкий зв'язок дитинчат з батьками та фракторами зовнішнього середовища. Тому навіть відносно м'які стресові впливи в цей період позначаються на формуванні поведінки. Можливі різні варіанти реалізації емоційного стресу - як розвиток стійкості, так і соматовегетативних розладів або неврозів [2].

Загалом багатофракторна обумовленість психосоматичних захворювань залучає велику кількість змінних, підтверджених клінічною практикою: спадкова конституція, родові травми; захворювання, випадкові травми в дитячому віці, характер догляду за дитиною, емоційний клімат в родині, особистісні риси батьків і сиблінгів, фрізичний та емоційний досвід в інтимних і виробничих відносинах. Лише врахування всіх цих категорій в їх взаємодії здатне забезпечити адекватний етіологічний підхід [1]. Поряд з цим підкреслюється роль в походженні психосоматичних порушень тривоги, пригнічених імпульсів, фррустрації, почуття неповноцінності і провини.

Серед основних тлумачень, накопичених в науковій літературі щодо психосоматики дітей $[2,4,7,10,14]$,

виділимо наступні чинники:

- відсутність захищеності в ранньому дитинстві, порушення безпеки через розлуку з батьками або нездорові сімейні відносини;

- внутрішній конфрлікт, протиріччя свідомого і несвідомого;

- фрізіологічне та психологічне перенавантаження, накопичення стресів, що призводить до виснаження захисних адаптаційних резервів організму;

- академічні перевантаження;

- характерна картина особистості, типові психологічні і поведінкові проблеми, що впливають на виникнення, перебіг і лікування хвороби;

- реакція на фрустрації, несприятливі психогенні впливи, переробка міжособистісних конфліктів, при яких індивід не бачить виходу з ситуації, «втеча у хворобу» як неправильний вихід із соціальних негараздів;

- конституційні властивості нервово-психічної діяльності та порушення ЦНС (слабкий тип реагування, емоційна нестабільність, вразливість);

- негативні емоції та депресивні стани, що впливають на імунну систему, гормональний стан та периферичну фрізіологічну активацію;

- надмірне фокусування на фрізичному самопочутті; надцінна переконаність пацієнта у правильності власної внутрішньої картини хвороби;

- ефект навіювання іншою особою (вербальні посилання батьків) або самонавіювання, «органічна мова», коли хвороба виступає фізичним втіленням фрази (наприклад, «у мене серце за нього болить» і т. ін.).

- симптоматика має певну приховану мету, вигоду, неусвідомлена бажаність захворювання (наприклад, напад позбавляє від значущих проблем, привертає увагу та турботу близьких людей);

- самопокарання (наприклад, дитина здійснює вчинок, неприпустимий з точки зору її вихователів. Тоді у дитини з'являється почуття провини, а вина шукає покарання, зокрема - у вигляді травм і соматичних порушень);

- фон несприятливих сімейних та інших соціальних факторів, що впливає на набуті схильності, поведінкові звички: неправильний режим дня, хибні виховні прийоми, відсутність єдиного підходу до дитини, незадовільні умови для розвитку самостійної діяльності і т. ін.;

- хворобливий, травматичний досвід минулого, при цьому має значення психічний та фрізичний стан людини під час дії психотравмуючих подій.

Перераховані фрактори беруть участь у фрормуванні розладів через різні механізми: вони роблять дитину вразливою до стресів; ускладнюють психологічний і біологічний захист; закріплюють фізіологічні реакції. При цьому кожний віковий період в житті дитини має специфічні особливості, наслідки яких можуть стати фоном для розвитку психосоматичних розладів.

Серед описаних механізмів важливу роль відіграють фрактичний стан навколишнього середовища, умови існування людини, а також їх суб'єктивна переробка у психіці. Тому коротко зупинимось на особливостях гірської місцевості та їх ролі у виникненні психосоматичних захворювань.

Несприятливі природно-господарські особливості (нестабільний суворий клімат, мале забезпечення орними землями, транспортна недоступність, складні ландшафтні умови, короткий період вегетації рослин тощо) неминуче породжує специфрічні проблеми, яких не знають низинні, особливо міські жителі. В Україні гірські території є депресивними за економічним станом і темпом суспільного розвитку. Проблему зайнятості жителі часто вирішують за рахунок трудової міграції. В цих умовах діти з раннього віку залучаються до посильної трудової діяльності, допомоги у домашньому господарстві (догляд за тваринами,будівництво, збір грибів і ягід). Крім того, життя мешканців супроводжується катастрофічними екологічними явищами - загрозливі повені, снігові замети, ерозія ґрунтів, забруднення поверхневих і підземних вод, вітровали, зустрічі з хижаками. Описані численні проблеми функціонування шкіл в гірській місцевості: віддаленості від осель, незадовільний санітарно-гігієнічний стан, кадрова та методологічна незабезпеченість (В. Д. Хрущ, І. Б. Червінська та ін.) [9].

Несприятливі умови існування негативно відображаються на стані здоров'я, вимагають посилення оздоровлюючого впливу на дітей. 3 іншого боку, це унікальне еколого-етнічне середовище з багатими духовними традиціями та фрілософрією життєустрою. Рідкозаселеність є джерелом тісного спілкування людини 3 первісною природою. Відмічені територіальна спільність, одностайність турбот та інтересів, тісні взаємовідносини, приятельські форми спілкування людей різного віку, професій, поколінь. 
Довкілля має потужний формуючий вплив на становлення особистості дитини, їі світосприймання та світорозуміння. Особливості життя, своєрідна «боротьба за виживання» формують особливі стереотипи поведінки іхарактерні риси. Відмічені психологічні аспекти розвитку під впливом гірського середовища: просторова мобільність; особливості ігор і відпочинку; консервація локальної культури; міжпоколінні інформаційні традиції та типові звички; перебування дітей поза дитячими колективами, серед дорослих тощо[9]. О. Хрущ пише, що умови життєдіяльності, які примушують покладатися на себе, формують витривалих загартованих людей. Разом з тим відмічені негативні психологічні риси горян: нетерпимість до іншої думки, гнівливість; злопам'ятність; необґрунтована наполегливість та впертість; заздрісність; різка зміна психічних станів; насторожено-підозріле ставлення до незнайомців та ін. [13].

Поширеність заробітчанства у замкненому соціально-природному просторі загрожує демографрічними проблемами. Звертає на себе увагу специфічне спотворення сімейних стосунків - багато дітей залишаються без опіки батька й матері. Якщо в повоєнні роки заробітчанами були переважно чоловіки, то для сучасної трудової міграції характерна протилежна ситуація. Жінки, що мають більшу затребуваність у сфері обслуговування, масово від"їжджають за кордон, залишаючи дітей на виховання батьків та бабусь. У свою чергу, сезонні роботи позбавляють багатьох батьків можливості особисто і систематично виховувати своїх дітей.

На специфічний аспект проблеми зайнятості у гірському середовищі звертає увагу Ю.М. Москаленко. Відсутність перспектив працевлаштування створює соціальне напруження та втрату смисложиттєвих орієнтирів, що передається від батьків дітям і спостерігається вже у старшокласників. Діти змалечку переймають відповідні соціальні стандарти, серед яких домінує цінність матеріального благополуччя. В контексті психосоматики привертає увагу «невроз безробітного», провідним симптомом якого є апатія. Особистість, позбавлена участі у продуктивній праці, переживає спустошеність, стає байдужою до всього, а згодом стає ворожою [8].

Зрозуміло, що в осіб, які народилися і постійно мешкають у гірських районах, виробилися спадково обумовлені механізми адаптації до суворих умов. Але в умовах фрізичного або розумового перевантаження, на фоні зниження імунітету відбувається зрив компенсаторних реакцій, що спричиняє дезадаптацію та виникнення хвороб. До відомих і описаних вище психосоматичних механізмів можна додати інші, специфічні саме для сільської місцевості високогірних районів:

- обмеженість кола соціальних контактів, сила думки громади, авторитет старших може бути причиною надмірної навіюваності в дітей, пасивно-захисних реакцій; нездатності гнучко реагувати, пристосовуватися до змін і вирішувати проблемні ситуації міжособистісного характеру;

- нестача уваги та виховання батьків через постійну зайнятість роботою;

- низький рівень загальної та соціальної компетентності через погіршення освітніх можливостей, відсутність центрів культури;

- активна участь дітей в процесі життєзабезпечення та діяльності родини; розвиток ранньої самостійності у вирішенні життєвих проблем;

- втрата провідних цінностей та смислу життя, невизначеність життєвих перспектив;

- розуміння власної залежності від природних сил, сезонних ритмів.

Описані вище особливості середовища, очевидно, спричиняють особливу картину стану здоров'я населення. Наведемо деякі клінічні дані.

Н.І. Ковтюк (2003) порівнювала репродуктивне становлення дівчат з міста Чернівці та гірських селищ. Обстеження показало, що дівчата, які проживають в гірських селищах, відстають у загальних фрізичних показниках (маса тіла, ріст, загальна гармонійність розвитку, статеве дозрівання). У них домінує інвертований статевий розвиток, що сам по собі $€$ ранньою ознакою маніфестації ендокринних порушень репродуктивної функції. У 50 \% виявлена патологія щитоподібної залози, у 44 \% - гінекологічні захворювання з порушенням менструального циклу. Авторка розцінює отримані клінічні дані як генетично обумовлений фактор та вплив умов високогір'я [5].

Українські педіатри звертають увагу на метаболічний синдром, який поєднує абдомінальне ожиріння, зниження толерантності до вуглеводів, дисліпідемію, артеріальну гіпертензію та інші ускладнення, які призводять до соціальної дезадаптації й інвалідності. За даними досліджень, на Прикарпатті (2016) вияви метаболічного синдрому в гірських районах зустрічаються у 1,5-2 рази частіше порівняно з рівнинною місцевістю. При цьому діти мають вищі значення артеріального тиску, прояви гіпертензії у нічний час [11]. Дослідження О.С. Бобрикович (2012) демонструють виразне ожиріння серед дітей гірських районів. Паралельно із наростанням ступеня ожиріння збільшуються порушення ліпідного і вуглеводного обміну, що є важливим пре диктором розвитку атеросклерозу і цукрового діабету [3].

Для подібної клінічної картини існують об'єктивні екологічні умови: йододефіцит, незбалансоване харчування, низький вміст кисню в повітрі. Водночас описані хвороби можуть бути пояснені за допомогою механізмів психогенного характеру та впливів специфічного соціального середовища.

Цукровий діабет - хвороба, пов'язана з дефектом секреції інсуліну, що вимагає обов'язкової інсуліно-замісної терапії для компенсації вуглеводного обміну. На дитячий вік припадає до 8\% загального числа хворих. Пік захворюваності припадає на 3-4 роки і 6-8 років, а також підлітків 11-14 років [4; 12]. Традиційно вважається, що діабет II типу (при збереженій функції секреції інсуліну) має психогенне походження, але для дітей він не характерний. Психічні фрактори суттєво впливають на течію хвороби. Особливе значення надається властивому хворим почуттю незахищеності, емоційної занедбаності, сильне бажання турботи про себе і активний пошук залежності від інших. Описані відмінність між дорослим (тип II) і ювенільним цукровим діабетом (тип I). Для хворих юнацьким діабетом характерні шизоїдні риси (закритість, мінімальний прояв емоцій, невміння встановлювати щирі контакти з іншими), при навантаженнях вони демонструють заперечення і селективне сприйняття проблем [7].

Порушення функцій щитовидної залози проявляється у двох формах: гіпертиреоз та гіпотиреоз. Спектр біологічних ефектів тиреоїдних гормонів дуже широкий, оскільки рецептори до них наявні практично на всіх клітках. Збільшення залози незалежно від причини позначається терміном «зоб». 
Ендемічний зоб розвивається в результаті хронічного дефіциту йодидів у навколишньому середовищі (а отже, і в продуктах харчування), він типовий для віддалених від моря гірських районів. Оскільки Західні регіони України історично є місцевістю з поширеністю ендемічного зобу, зупинимося на цій проблемі більш детально. Лікарів турбує вплив йодної недостатності на розумовий розвиток (особливо в перші роки життя). Діти з ендемічним зобом гірше навчаються в школі, частіше хворіють, анемічні. Проявом важкого ступеня хвороби $є$ кретинізм, зумовлений порушенням функцій ЦНС. На подолання йодної недостатності спрямовані регулярні зусилля державних інституцій в сфері охорони здоров'я (починаючи з середини XX ст., коли в окремих селах Закарпаття захворюваність населення сягала до $80 \%$ ). За епідеміологічними даними у 2007p., показане суттєве поліпшення ситуації, хоча йодне забезпечення в гірських селах залишається недостатнім. Поширеність ендемічного зобу залежить від наявності у торгівлі продуктів, що містять йод, їх вартості, достатку сім'ї, санітарних і побутових умов [6].

Розвиток спорадичного зоба не пов'язаний з місцевістю, його причиною є збільшена потреба організму в йоді, наприклад, у пубертатному періоді. Однак у більшості випадків джерело хвороби установити не вдається, що відкриває простір для психосоматичних тлумачень. В цьому ж контексті привертає увагу аутоімунний тиреоїдит, що розвивається в підлітковому віці (у дівчат в 10 разів частіше); пошкодження обумовлене реакцією власного організму проти тканини щитовидної залози [12].

3 точки зору психосоматики, захворювання щитовидної залози пов'язані із здатністю активізувати життєві процеси і прискорено зростати (гіпертиреоз); або ж сповільнюватись і уникати перевантажень (гіпотиреоз).

У процесі набуття схильності до гіпертиреозу важливі ранні сімейні впливи, умови існування в дитинстві відсутність захищеності, незадоволене бажання прихильності. Таких дітей змалечку примушують до такого рівня самостійності, з яким вони не в змозі впоратися і до якого не готові (це явище характерне для життя в гірській місцевості). Наслідком збільшеної секреції тиреоїдних гормонів є руховий і душевний неспокій, легка збудливість, дратівливість. Незвичайна чутливість створює підвищений рівень діяльності індивіда. Вони справляють враження зрілих, адаптованих особистостей, але насправді за відповідальністю та працьовитістю приховується страх [4; 7].

Провідний симптом гіпотиреозу - уповільнення психічних реакцій. У хворих спостерігається стомлюваність, порушення пам'яті, сонливість, мерзлякуватість тощо. Провідними ознаками у дітей є сповільнення росту, фізична та розумова млявість. Для відповідної картини особистості характерні незацікавленість, безініціативність у повсякденній діяльності та соціальному житті (описані вище як наслідок економічної депресивності регіону). Часто гіпотиреоз розвивається після того, як людина відмовляється від досягнення бажаної мети, залишає надію і підпорядковує своє життя неприємному розпорядку, це своєрідний «сидячий емоційний страйк» [1, с. 7].

Ожиріння - хронічне захворювання, що проявляється надмірним накопиченням жирової тканини внаслідок дисбалансу споживання і витрати енергії. В основі хвороби лежить психовегетативне стимулювання структур гіпоталамусу, що відповідають за відчуття голоду і насичення. Часто серед психологічних причин переїдання називають нестачу позитивних емоцій. Воно служить захистом від почуття втрати, особливо при депресивних переживаннях. Їжа стає замінником, що задовольняє і заспокоює людину.

У клінічному дослідженні дітей від 2 до 17 років з різноманітними ендокринними захворюваннями (Ю. Ф. Антропов, Ю. С Шевченко, 2002), показано, що динаміка патології у дітей характеризується поступовою, через часті загострення, трансформацією функціональних порушень в органічні. Відносно часто, порівняно з виникненням розладів в інших системах, відзначається гостре виникнення розладів, нерідко внаслідок психотравми. Щодо психологічних особливостей, що супроводжують ендокринні хвороби, близько 50 \% продемонстрували порушення ранніх стосунків з матір'ю, несприятливі стилі виховання. В 67 \% випадків виявлені патологічні відхилення особистості батьків (тривожно-недовірливі, афективно збудливі риси матерів). Для самих дітей характерна резидуально-органічна недостатність ЦНС, акцентуації рис характеру з проявами лабільності. У всіх без винятку хворих виявлені різноманітні депресивні стани: астенічні, тривожні, тужливі. Звідси рекомендація застосовувати в терапії ендокринних хвороб антидепресивні засоби. Проведення індивідуальної психотерапії (а у дітей до 10 років сімейної терапії) сприяє одужанню навіть хворих, до цього стійких відносно традиційного симптоматичного лікування [2].

Взагалі психологічна реабілітація соматичної патології ґрунтується на постулаті первинності психологічних фракторівта можливості відновлення здоров'я через вплив на особистість дитини. При цьому сугестивні методики некорисні, оскільки більшість хворих знаходяться у субдепресивному стані схильні до навіювань і залежні. Натомість застосування засобів, які передбачають активну участь пацієнта, дозволяє позбавити його від психічної залежності і соматичного страждання. Обов'язковою умовою успішної реабілітації є формування установки на відновлення власного здоров'я, впевненості в ефективності реабілітації [7; 10]. В лікуванні успішно використовуються раціональна і когнітивна психотерапія, трансактний аналіз, психосинтез, символдрама, арт-терапія, гештальт-терапія, позитивна терапія. Адекватне використання психотерапії має профілактичну спрямованість, запобігає формуванню психогенних розладів в наступному.

Завершальний етап такої комплексної медико-психологічної терапії передбачає індивідуальні рекомендації, що стосуються подолання психічних і фізичних навантажень, формування здорового способу життя, оптимальних життєвих цілей. У випадку дітей ця робота спрямована на батьків (при цьому ми пам'ятаємо, що часто саме поведінка дорослих та неадекватне виховання $€$ причиною хвороби). Оскільки в корекції особистісних розладів мають високу ефективність культурологічні та педагогічні методики, постає питання відповідної профрілактичної роботи в школі, формування повноцінної особистості з відповідальним ставленням до власного здоров'я. Велику роль відіграє в цьому поінформованість щодо взаємозв'язків внутрішніх психічних станів, хвороб та способу життя, вміння регулювати свої емоційні прояви, адаптивно долати стреси, навантаження та життєві проблеми.

\section{ВИСНОВКИ ТА ПЕРСПЕКТИВИ ПОДАЛЬШИХ ДОСЛІДЖЕНЬ}

Проведений аналіз показав, що психологічне здоров'я жителів гірської місцевості, їх духовні сили є необхідною умовою життєзабезпечення в складних кліматичних і соціальних умовах. Хвороби спричиняє сукупність фрізіологічних 
і психічних впливів, що доповнюють один одного. Стан тіла людини є втіленою історією її родини, пережитих емоцій, психологічних травм, накопиченого життєвого досвіду, поглядів, сформованих на фоні певних природних і соціальних факторів. Психогенні розлади у дітей характерні також у силу їх вікових особливостей: недосконала центральна нервова регуляція вегетативних функцій, перевага емоційних способів реагування. Тому пошук ефективних шляхів лікування полягає у зміні деструктивних для організму способів емоційного реагування і поведінки. Людина, що знаходиться в гармонійних відносинах зі своїм середовищем, може перенести значні навантаження, уникнувши хвороби.

\section{СПИСОК ВИКОРИСТАНИХ ДЖЕРЕЛ}

[1] Александер Ф. Психосоматическая медицина. Принципы и практическое применение. М.:ЭКСМО-Пресс, 2002. 352 с.

[2] Антропов Ю. Ф., Шевченко Ю. С.Психосоматические расстройства и патологические привычные действия у детей и подростков. М. : Изд-во Ин-та Психотерапии, НГМА, 2000. 320 с.

[3] Бобрикович О.С. Характеристика ліпідного і вуглеводного обміну у дітей з проявами метаболічного синдрому. Галицький лікарський вісник. 2012. Т. 19. № 2. С. 8-11

[4] Исаев Д. Н. Эмоциональный стресс, психосоматические и соматопсихические расстройства у детей. СПб. : Речь, 2005.400 с.

[5] Ковтюк Н. І. Комплексна оцінка розвитку дівчат шкільного віку Чернівецького регіону : автореф. дис. на здобуття наук. ступеня канд. мед. наук : спец. 14.01.10. Львів, 2003. 20 с.

[6] Кравченко В. І. Проблема йододефіциту в Україні / В. І. Кравченко; Інститут ендокринології та обміну речовин ім. В.П. Комісаренка AMH України. URL: http://medstrana.com/articles/300/

[7] Малкина-Пых И. Г. Психосоматика: Справочник практического психолога. М. : Эксмо, 2005. 992 с.

[8] Москаленко Ю. М. Віктор Франкл і його теорія екзистенційного вакууму в контексті розвитку особистості в гірських умо-вах. Гірська школа Українських Карпат. 2007. № 2-3. С. 89-92.

[9] Науково-дослідний проект «Гірська школа. Стан. Проблеми. Перспективи розвитку» / Прикарпатський національний ун-т імені Василя Стефаника ; керівник проекту В. Д. Хрущ. URL: http://mountainschool.pu.if.ua/node/69

[10] Хайтович М. В., Майданник В.Г., Ковальова О.А. Психотерапія в педіатрії. Ніжин : Аспект-Поліграф, 2003. 216 с.

[11] Характеристика артеріальної гіпертензії в дітей з виявами метаболічного синдрому на Прикарпатті / О.Л. Цимбаліста, О.С. Бобрикович та ін. Український журнал дитячої ендокринології. 2016. № 2. С. 75-78.

[12] Хвороби ендокринної системи у дітей / Г.С. Сенаторова, Т.В. Чайченко, Л.Г. Тельнова та ін. Харків, ХНМУ, 2011. 38 с.

[13] Хрущ О. Гори і психологія горян. Гірська школа Українських Карпат. 2007. № 2-3. С. $127-131$.

[14] Somatoform disorders / O. Fiertag, S. Taylor, A. Tareen \& E. Garralda. IACAPAP e-text book of Child and Adolescent Mental Health Editor / ed. J.Rey; Department of Medicine of Imperial College London, 2012 URL: http://iacapap.org/ iacapap-textbook-of-child-andadolescent-mental-health).

\section{REFERENCES (TRANSLATED AND TRANSLITERATED)}

[1] Aleksander F. Psihosomaticheskaja medicina. Principy i prakticheskoe primenenie (Psychosomatic medicine. Principles and practical application). M. : JeKSMO-Press, 2002. 352 s.

[2] Antropov Ju. F., Shevchenko Ju. S. Psihosomaticheskie rasstrojstva i patologicheskie privychnye dejstvija u detej i podrostkov (Psychosomatic disorders and pathological habitual actions in children and adolescents). M. : Izd-vo In-ta Psihoterapii, NGMA, 2000.320 s.

[3] Bobrykovych O.S. Kharakterystyka lipidnoho i vuhlevodnoho obminu u ditey z proyavamy metabolichnoho syndrome (Characteristics of lipid and carbohydrate metabolism in children with manifestations of metabolic syndrome). Halyts'kyy likars'kyy visnyk. 2012. T. 19, № 2. S. 8-11.

[4] Isaev D. N. Jemocional'nyj stress, psihosomaticheskie i somatopsihicheskie rasstrojstva u detej (Emotional stress, psychosomatic and somatopsychiatric disorders in children). SPb. : Rech', 2005. $400 \mathrm{~s}$.

[5] Kovtyuk N. I. Kompleksna otsinka rozvytku divchat shkil'noho viku Chernivets'koho rehionu (Comprehensive assessment of the development of girls of school age in the Chernivtsi region): avtoref. dys. na zdobuttya nauk. Stupenya kand. med. nauk : spets. 14.01.10. L'viv, 2003. $20 \mathrm{~s}$.

[6] Kravchenko V. I. Problema yododefitsytu v Ukrayini (The problem of iodine deficiency in Ukraine) / V. I. Kravchenko; Instytut endokrynolohiyi ta obminu rechovyn im. V.P. Komisarenka AMN Ukrayiny. URL: http://medstrana.com/articles/300/

[7] Malkyna-Pykh Y. H. Psykhosomatyka: Spravochnyk praktycheskoho psykholoha (Psychosomatics: A Handbook of Practical Psychology). M. : Эksmo, 2005. $992 \mathrm{~s}$

[8] Moskalenko Yu. M. Viktor Frankl i yoho teoriya ekzystentsiynoho vakuumu v konteksti rozvytku osobystosti v hirs'kykh umovakh (Victor Frankl and his theory of existential vacuum in the context of personality development in mountainous conditions). Hirs'ka shkola Ukrayins'kykh Karpat. 2007. № 2-3. S. 89-92.

[9] Naukovo-doslidnyy proekt «Hirs'ka shkola. Stan. Problemy. Perspektyvy rozvytku» (Research project "Mountain School. State. Problems Development prospects") / Prykarpat-s'kyy natsional'nyy un-t imeni Vasylya Stefanyka ; kerivnyk proektu V. D. Khrushch. URL: http://mountainschool.pu.if.ua/node/69

[10] Khaytovych M. V., Maydannyk V. H., Koval'ova O. A. Psykhoterapiya v pediatriyi (Psychotherapy in pediatrics). Nizhyn : Aspekt-Polihraf, 2003. $216 \mathrm{~s}$.

[11] Kharakterystyka arterial'noyi hipertenziyi v ditey z vyyavamy metabolichnoho syndromu na Prykarpatti (Characteristics of arterial hypertension in children with manifestations of metabolic syndrome in the Carpathian region) / O. L. Tsymbalista, O. S. Bobrykovychtain. Ukrayins'kyy zhurnal dytyachoyi endokrynolohiyi. 2016. № 2. S. 75-78.

[12] Khvoroby endokrynnoyi systemy u ditey (Diseases of the endocrine system in children) / H.S. Senatorova, T.V. Chaychenko, L.H. Tel'novatain. Kharkiv, KhNMU, 2011. $138 \mathrm{~s}$.

[13] Khrushch O. Hory i psykholohiya horyan (Mountains and psychology of highlanders). Hirs'ka shkola Ukrayins'kykh Karpat. 2007. № 2-3. S. $127-131$

[14] Somatoform disorders / O. Fiertag, S. Taylor, A. Tareen \& E. Garralda. IACAPAP e-text book of Child and Adolescent Mental Health Editor / ed. J.Rey; Department of Medicine of Imperial College London, 2012 URL: http://iacapap.org/ iacapap-textbook-of-child-andadolescent-mental-health). 